DEVELOPMENT OF MANAGEMENT

AND ENTREPRENEURSHIP METHODS

ON TRANSPORT, № 3 (76), 2021
РОЗВИТОК МЕТОДІВ

УПРАВЛІННЯ ТА ГОСПОДАРЮВАННЯ

НА ТРАНСПОРТІ, № 3 (76), 2021
УДК 347.79

JEL Classification K 33

DOI 10.31375/2226-1915-2021-3-64-73

\section{ПРАВОВЕ РЕГУЛЮВАННЯ МІЖНАРОДНИХ ЧАРТЕРНИХ ТА ЛІНІЙНИХ МОРСЬКИХ ПЕРЕВЕЗЕНЬ}

А.А. Пальченко

старший викладач кафедри «Морське право» О.С. Пішанська

магістр спеціальності «Право»

Одеський національний морський університет, Одеса, Украӥна

Анотація. Правове регулювання відносин, що виникають із здійснення міжнародних перевезень, має свою спещифіку. Найважливіші умови визначені у міжнародних угодах - конвенціях, які є основним джерелом регулювання у иій сфері відносин. Угоди містять переважно уніфіковані матеріальноправові норми, необхідні для врегулювання колізій, щзо найчастіше виникають при регулюванні питань в сфері міжнародних перевезень. Слід зазначити, що міжнародні транспортні конвениії складаються й з колізійних норм, до яких звертаються у разі відсутності уніфікованих матеріально-правових норм. Як правило, колізійні норми відсилають до начіонального законодавства, а й інколи - $і$ до норм міжнародних конвенцій. Норми конвениій про міжнародні перевезення $\epsilon$ імперативними щодо договорів перевезення, оформлених транспортним документом - коносаментом. Як правило, колізійні норми відсилають до начіонального законодавства, а й інколи - $i$ до норм міжнародних конвенцій. Норми конвентцій про міжнародні перевезення $\epsilon$ імперативними щодо договорів перевезення, оформлених транспортним документом - коносаментом. Відносини у сфері морського судноплавства у багатьох випадках залишаються підпорядкованими положенням внутрішнього морського права, які повинні визначатись за допомогою колізійних норм. Однак, оскільки загально визнаних колізійних норм, що встановлені міжнародними договорами, знов таки небагато, всі відповідні питання вирішуються на рівні наиіональної судової практики, а вона також є різною.

Ключові слова: конвечія, коносамент, чартер, морські перевезення, морський порт.
УДК 347.79

JEL Classification $K 33$

DOI 10.31375/2226-1915-2021-3-64-73

\section{ПРАВОВОЕ РЕГУЛИРОВАНИЕ МЕЖДУНАРОДНЫХ ЧАРТЕРНЫХ И ЛИНЕЙНЫХ МОРСКИХ ПЕРЕВОЗОК}

А.А. Пальченко

старший преподаватель кафедры «Морское право»

Е.С. Пишанская

магистр специальности «Право»

Одесский национальний морской университет, Одесса, Украина

Аннотация. Правовое регулирование отношений, возникающих по осуществлению международных перевозок, имеет свою специфику. Важнейшие условия определень в международных соглашениях - конвенциях, которые являются основным источником регулирования в этой сфере отношений. Соглашения содержат преимушественно унифицированные материально-правовые нормы, необходимые для урегулирования коллизий, наиболее часто возникаюшие при регулировании вопросов в сфере международных перевозок. Следует отметить, что международные транспортные конвенции складываются и с коллизионных нормыл, к которым обрашаются в случае отсутствия унифичированных материально-правовых норм. Как правило, коллизионные нормы отсылают к начиональному законодательству, но и иногда $-u \kappa$ нормам международных конвенций. Нормы конвенций о международных перевозках являются императивными по договорам перевозки, оформленных транспортным документом - коносаментом. Как правило, коллизионные нормы отсылают к начиональному законодательству, но и иногда - ик нормам международных конвениий. Нормы конвениий о международных перевозках являются императивными по договорам перевозки, оформленных транспортным документом - коносаментом. Отношения в сфере морского судоходства во многих случаях остаются подчиненными положениям внутреннего морского права, которые должны определяться с помощью коллизионных норм. Однако, поскольку обшепризнанных коллизионных норм, установленных международными договорами, опять-таки немного, все соответствуюшие вопросы решаются на уровне национальной судебной практики, а она также различна.

Ключевые слова: конвенция, коносамент, чартер, морские перевозки, морской порт.

(C) Пальченко А.А., Піщанська О.С., 2021 
UDC 347.79

JEL Classification K 33

DOI 10.31375/2226-1915-2021-3-64-73

\title{
LEGAL REGULATION OF INTERNATIONAL CHARTER AND LINER SHIPPING
}

\author{
Alla Palchenko \\ senior lecturer at the Department of Maritime Law, ONMU \\ ORCID: 0000-0001-9686-4660 \\ e-mail: nai-ce@bigmir.net \\ Elena Pishchanskaya \\ Master in «Law» \\ Odessa National Maritime University, Odessa, Ukraine
}

\begin{abstract}
Legal regulation of relations arising from the implementation of international transport has its own specifics. The most important conditions are defined in international agreements - conventions, which are the main source of regulation in this area of relations. The agreements contain mainly unified substantive legal norms necessary for the settlement of conflicts that most often arise in the regulation of issues in the field of international transport. It should be noted that international transport conventions also consist of conflict-of-law rules, which are invoked in the absence of unified substantive law. As a rule, conflict-of-law rules refer to national legislation, but sometimes also to the norms of international conventions. The norms of the conventions on international transportation are imperative for contracts of carriage, executed by a transport document - a bill of lading. As a rule, conflict-of-law rules refer to national legislation, but sometimes also to the norms of international conventions. The norms of the conventions on international transportation are imperative for contracts of carriage, executed by a transport document - a bill of lading. Relations in the field of maritime shipping in many cases remain subject to the provisions of domestic maritime law, which must be determined by conflict of laws rules. However, as there are again few generally accepted conflict-of-law rules established by international treaties, all relevant issues are resolved at the level of national case law, and it is also different. In connection with the development of the world economy and international economic relations, the question of the ability and degree of influence of maritime transport on them plays an important role. Maritime shipping is central to a single global transport system. Maritime transport is already in its format of activity is an international industry, and concerns the activities of the carrier for the movement of goods or passengers from the port of departure to the port of destination.
\end{abstract}

Keywords: convention, bill of lading, charter, sea transportation, seaport.

Постановка проблеми. Сучасний рівень розвитку економіки України характеризується значною неста- більністю, проте поглиблення інтеграції у світове господарство не втрачає своєї актуальності. Внаслідок цьо- 
DEVELOPMENT OF MANAGEMENT

AND ENTREPRENEURSHIP METHODS ON TRANSPORT, № 3 (76), 2021
РОЗВИТОК МЕТОДІВ

УПРАВЛІННЯ ТА ГОСПОДАРЮВАННЯ

НА ТРАНСПОРТІ, № 3 (76), 2021 го зростає роль міжнародного ринку транспортних послуг, що посилює актуальність розробок, які сприяють підвищенню якості логістичних послуг.

Основна маса перевезень припадає саме на морський транспорт, i вона щорічно зростає. Перевага даного виду транспорту полягає у його дешевизні, а також у можливості перевозити різноманітний вантаж. Міжнародні морські перевезення пов'язані 3 перевезенням вантажів, пасажирів та їх багажу між двома різними країнами та перетинанням кордону.

Огляд останніх досліджень та публікацій. Важливі питання досліджуваної проблеми розглядалися в багатьох працях вітчизняних учених, зокрема: Г.О. Бараненка, I.М. Колегаєва, О.М. Котлубая, О.І. Лапкіна, Т.Г. Логутової, Л.М. Наумової, Л.Л. Ніколаєвої, І.М. Пархоменко, І.В. Познанської, М.М. Полторацького, М.Т. Примачова, К.Л. Семенчук, Л.Л. Сотниченко, А.О. Філі-пенка, Т.I. Фрасинюк, М.С. Євсік, П.М. Карась, I.М. Манаєнко, І.В. Просяник, Л.М. Філіпішиної, М.Л. Шелухіна, Е.В. Щеникова та ін.

Завдання дослідження. Метою статті $\epsilon$ огляд сучасних наукових тенденцій та узагальнення досліджень учених в галузі морського транспорту та морських перевезень, аналіз ступеню розкриття теми $з$ погляду світової морської торгівлі в умовах сьогодення, а також порівняння цих досліджень із сучасними публікаціями науковців.

Основний матеріал дослідження. Постає питання необхідності постійного удосконалення системи стратегічного логістичного управ- ління морських портів, яка сприятиме стимулюванню господарської діяльності, зростанню конкурентоспроможності, спонуканню до втілення інновацій, вирішенню виникаючих протиріч між працівником і роботодавцем та інших позитивних результатів в складних умовах їх господарювання.

Більша частина правових питань виникає саме під час морських перевезень, що пояснюється великою кількістю відносин, а також різним характером джерел правового регулю-вання - норми міжнародного права, норми національного законодавства, морські звичаї тощо. Досить часто законодавство країн навіть не має спеціальних колізійних норм для регулювання морських перевезень, а тому ці питання визначаються в основному судовою практикою.

Правове регулювання відносин, що виникають із здійснення міжнародних перевезень, має свою специфіку. Найважливіші умови визначені у міжнародних угодах - конвенціях, які є основним джерелом регулювання у цій сфері відносин. Угоди містять переважно уніфіковані матеріально-правові норми, необхідні для врегулювання колізій, що найчастіше виникають при регулюванні питань в сфері міжнародних перевезень. Слід зазначити, що міжнародні транспортні конвенції складаються й 3 колізійних норми, до яких звертаються у разі відсутності уніфікованих матеріально-правових норм. Як правило, колізійні норми відсилають до національного законодавства, а й інколи - i до норм міжнародних конвенцій. Норми конвенцій про міжнародні перевезення $є$ імперативними щодо договорів перевезення, оформлених 
DEVELOPMENT OF MANAGEMENT

AND ENTREPRENEURSHIP METHODS ON TRANSPORT, № 3 (76), 2021
РОЗВИТОК МЕТОДІВ

УПРАВЛІННЯ ТА ГОСПОДАРЮВАННЯ

НА ТРАНСПОРТІ, № 3 (76), 2021 транспортним документом - коносаментом. Слід зазначити, що перевезення, які оформлюються чартером, регулюються національним законодавством країни, звичаями портів, проформами чартерів тощо. Специфіка регулювання міжнародних перевезень може виявлятися у відображенні норм міжнародних договрів у національному законодавстві без попередньої ратифікації, підписання або ж приєднання до них. Таке явище відоме за назвою рецепційного ефекту міжнародного договору. Воно є достатньо поширеним. До речі, Україна використовує цей підхід. Так, правила Брюссельської конвенції щодо уніфікації деяких правил про коносамент 1924 р., які застосовуються до морських перевезень, і в якій беруть участь близько 50 держав, сприйняті національним законодавством, ще майже 30 держав - без ратифікації чи приєднання до зазначеної Конвенції [3].

На сьогодні здійснення змішаних перевезень, транзит і контейнерні перевезення регулюються спеціальними нормами міжнародних чи національних актів.

У сфері правового регламентування міжнародних морських перевезень пасажирів основним міжнародно-правовим актом $є$ Конвенція про перевезення морем пасажирів i їхнього багажу. Як уже зазначалось, ця Конвенція прийнята в Афінах 1974 р. і одержала назву Афінська [8]. Вона об'єднала та доповнила положення раніше прийнятих:

- Брюссельської конвенції про уніфікацію деяких правил, що належать до перевезення пасажирів морем (1961 p.) [3];

- Міжнародної конвенції про уніфікацію деяких правил про перевезення морем багажу пасажирів, прийнятої в Брюсселі 1967 р. [7].

У1976 р. положення Афінської конвенції доповнені прийняттям у Лондоні Конвенції про обмеження відповідальності за морськими вимогами [8].

Першим правовим актом 3 визначення міжнародного статусу коносамента стала Брюссельська конвенція щодо уніфікації деяких правил про коносамент, прийнята Міжнародним морським комітетом 1924 р. Вона отримала назву Гаазькі правила, котрі набули чинності 2 червня 1931 р. У 1968 р. до неї прийнято додатковий протокол «Правила Вісбі», які стали чинними 6 грудня 1978 р. [3].

Гаазькі правила не мають чіткої структури, притаманної іншим міжнародним договорам у сфері перевезень. Конвенція складається лише 3 16 статей. 3 них змістовними (регулювання та регламентація договорів морського перевезення вантажів 3 коносаментів) $є$ всього 10 статей, останні 6 можна вважати додатковими, оскільки вони встановлюють процедури підписання Конвенції, приєднання до неї, іiі денонсації та ін.

Поняття «перевезення вантажу» фактично визначає тимчасові межі дії договору морського перевезення вантажу: 3 моменту завантаження на борт судна до моменту вивантаження 3 нього. I надалі за текстом Конвенції про періоди відповідальності перевізника за договором нічого не сказано, можна вважати, що договір перевезення охоплює весь період самого перевезення вантажу. Отже, відповідальність перевізника за договором також інкорпорована у зазначені тим- 
DEVELOPMENT OF MANAGEMENT

AND ENTREPRENEURSHIP METHODS ON TRANSPORT, № 3 (76), 2021
РОЗВИТОК МЕТОДІВ

УПРАВЛІННЯ ТА ГОСПОДАРЮВАННЯ

НА ТРАНСПОРТІ, № 3 (76), 2021 часові періоди. Тому період відповідальності перевізника за договором морського перевезення вантажу - не в межах «від дверей відправника до дверей одержувача» чи «від порту відправлення до порту призначення», а «від борту судна в порту відправлення до борту судна в порту призначення». Встановлені межі відповідальності за бажанням сторін договору перевезення можуть бути підвищені [8].

Незважаючи на те, що Афінська конвенція значно, порівняно 3 Брюссельськими, підвищила межі відповідальності морського перевізника, це не задовольнило деякі держави. Вони в односторонньому порядку збільшили їх, зокрема Англія - у 2, а Німеччина - у 3 рази. Так само вчинили й інші держави. Таке явище зумовлене розвитком інфляції та знецінення внаслідок цього валют. 3 огляду на це у положення Афінської конвенції стосовно меж відповідальності перевізника внесені зміни про їхнє підвищення, що відображено в Про-токолі до Афінської конвенції, прийнятому 1990 р., «Про зміни Афінської конвенції про перевезення морем пасажирів і їхнього багажу» 1974 р.

Конвенція ООН про договори міжнародного перевезення вантажу повністю або частково морем, що призвана регулювати питання міжнародного перевезення вантажу, підписано у вересні 2009 року у Нідерландах. 3 розширенням контейнерних перевезень, намаганням організувати перевезення вантажу на умовах «від двері до двері» в рамках єдиного договору, а також 3 розвитком практики використання електронних транспортних документів розробка вказаної Конвенції була в край необхідною [4].

Уніфікація права міжнародної торгівлі сприяє загальному економічному співробітництву між усіма державами на основі рівності, справедливості та загальних інтересів

Правове регулювання міжнародних морських перевезень вантажів уніфіковано на міжнародному правовому рівні. I це є позитивним моментом, так як уніфікація, як відомо, сприяє подоланню колізій різнонаціональних законів. 3 іншого боку, одночасна наявність міжнародно-правових норм, які регулюють одні й ті ж відносини по-різному, викликає певні питання щодо їх застосування, конкуренції норм різних міжнародних актів, i, таким чином, не тільки не сприяє одностайному врегулюванню спірних питань, а, навпаки, ускладнює «колізію». Отже, як свідчить практика міжнародних морських перевезень вантажів, ця сфера потребує подальшої уваги з боку фахівців усіх рівнів 3 точки зору розробки більш ефективного, тобто, 3 огляду на урахування інтересів усіх учасників перевезення, правового регулятора цих відносин.

Одним із нормативно-правових актів, що регулюють діяльність у сфеpi морських перевезень комплексним є КТМ України 1995 р., статті 131 та 132 якого визначають два види морських перевезень - каботажні: перевезення між портами України здійснюються суднами, що плавають під державним прапором України, а також суднами, що плавають під іноземним прапором за умови одержання на це дозволу центрального органу виконавчої влади, що забезпечує формування державної політики у сфері 
DEVELOPMENT OF MANAGEMENT

AND ENTREPRENEURSHIP METHODS ON TRANSPORT, № 3 (76), 2021
РОЗВИТОК МЕТОДІВ

УПРАВЛІННЯ ТА ГОСПОДАРЮВАННЯ

НА ТРАНСПОРТІ, № 3 (76), 2021 транспорту; та міжнародні перевезення: перевезення між портами України й іноземними портами можуть здійснюватися як суднами, що плавають під прапором України, так і за умови взаємності суднами, що плавають під іноземним прапором [1].

Перевезення вантажів здійснюється на підставі договору морського перевезення вантажу, за яким перевізник або фрахтівник зобов'язується перевезти доручений йому відправником вантаж із порту відправлення в порт призначення і видати його уповноваженій на одержання вантажу особі (одержувачу), а відправник або фрахтувальник зобов'язується сплатити за перевезення встановлену плату (фрахт) - ч. 1 ст. 133 КТМ [1].

Правовий режим морських перевезень більш складний порівняно 3 іншими видами міжнародних перевезень (пов'язано з розмаїттям цивільно-правових відносин, що виникають у сфері торгового мореплавства і відсутністю з ряду питань морського права міжнародних домовленостей, які сприяли б уніфікації умов цих перевезень).

Морські перевезення поділяються на 2 види - регулярні (лінійні) та нерегулярні (трампові) перевезення.

Лінійні перевезення $\epsilon$ більш прогресивною формою морських перевезень, бо мають такі переваги:

- регулярність здійснення 3 дотриманням строків, передбачених відповідним розкладом;

- відносно стабільні і завжди відомі наперед тарифи;

- використання для перевезень спеціалізованого тоннажу;

- доступність завдяки викорис- танню широкої мережі агентів. Проте, саме ці переваги спричиняють те, що тарифи на лінійні перевезення є значно більшими порівняно $з$ трамповими перевезеннями.

Ці перевезення здійснюються на підставі міжурядових угод, рідше за угодами між приватними судноплавними компаніями. Перевезення вантажу при цьому здійснюється на підставі лінійного коносаменту, а перевезення пасажирів та багажу - на підставі квитка.

Договір про морське перевезення трамповими суднами має назву чартера. Чартер (або договір фрахтування судна) являє собою договір, за яким одна сторона - перевізник (фрахтівник) зобов'язується перевезти вантаж 3 порту відвантаження у порт призначення, а інша - (вантажовідправник або вантажоотримувач) 30бов'язується надати вантаж і сплатити провізну плату (фрахт).

У чартерних перевезеннях права та зобов'язання сторін залежать від:

- характеру фрахтування;

- характеру надання судна у використання;

- умов самого чартеру.

За характером фрахтування розрізняються так званий повний чартер, коли власником вантажу орендується все судно, частковий - у випадках оренди певної частини судна, та каютний чартер при перевезенні невеликих партій вантажу.

Залежно від характеру надання судна у використання чартери поділяються на:

- чартер-партію (рейсовий чартер), коли має місце переміщення вантажу з порту в порт; 
DEVELOPMENT OF MANAGEMENT

AND ENTREPRENEURSHIP METHODS ON TRANSPORT, № 3 (76), 2021
РОЗВИТОК МЕТОДІВ

УПРАВЛІННЯ ТА ГОСПОДАРЮВАННЯ

НА ТРАНСПОРТІ, № 3 (76), 2021
- тайм-чартер, за яким судно орендується не тільки для здійснення перевезень, а й для досягнення інших пов'язаних 3 торговим мореплавством цілей (здійснення наукових досліджень тощо);

- дімайз-чартер-оренда «голого» судна 3 метою подальшого його використання на розсуд наймача, який зобов'язаний спорядити та найняти на нього команду за свій рахунок.

Морський чартер $є$ складною зовнішньоторговельною угодою, яка містить до 60-ти умов щодо судна, порядку його подачі, вантажу, який перевозиться, здійснення вантажних та розвантажувальних робіт, розрахунків за фрахтом, відповідальності фрахтівника тощо.

Стандартні умови проформ чартеру можуть змінюватись або доповнюватись за згодою сторін внесенням у чартер спеціальних застережень. Практично всі чартери складаються $з$ основної (стандартної) частини та адендумів, що закріплюють особливі умови фрахтування суден i перевезення вантажів. Тому, зазвичай, чартери укладають брокери, тобто спеціалізовані установи, що $є$ агентами власників суден, за спеціальну винагороду (брокерську комісію).

Договір чартеру може містити також умови щодо юрисдикції та права, яке підлягає застосуванню. Звичайним місцем розгляду спорів обирається місцеперебування відповідача або місто Лондон, де знаходиться всесвітньо відомий морський арбітраж, а застосовним правом - право держави, де чартер було виготовлено або у якій він практично реалізується.

У міжнародних морських пере- везеннях значну роль відіграють правила, які мають звичаєве походження.

Окрім кодифікації міжнародних звичаїв Інкотермс та інших кодифікацій, в міжнародних морських перевезеннях широкого розповсюдження набули і правила окремих портів.

Фрахтувальником i фрахтівником визнаються особи, що уклали між собою договір фрахтування судна (чартер).

Договір морського перевезення вантажу повинен бути укладений у письмовій формі.

Правовідносини між перевізником і одержувачем вантажу визначаються коносаментом. Умови договору морського перевезення, не викладені в коносаменті, обов'язкові для одержувача, якщо в коносаменті зроблено посилання на документ, в якому вони викладені. Коносамент виконує такі функції: засвідчує факт прийняття перевізником вантажу до перевезення; є товаророзпорядчим документом; виконує роль договору міжнародного морського перевезення.

Окрему групу перевезень складають перевезення пасажирів та їх вантажу, що здійснюється за договором морського перевезення пасажирів, за яким перевізник зобов'язується перевезти пасажира і його каютний багаж у пункт призначення, а в разі здачі пасажиром багажу - також доставити багаж у пункт призначення i видати його уповноваженій на отримання багажу особі; пасажир повинен сплатити встановлену плату за проїзд, а при здачі багажу - і плату за провезення багажу

Морські торговельні порти $€$ ключовою ланкою транспортно-логіс- 
DEVELOPMENT OF MANAGEMENT

AND ENTREPRENEURSHIP METHODS ON TRANSPORT, № 3 (76), 2021
РОЗВИТОК МЕТОДІВ

УПРАВЛІННЯ ТА ГОСПОДАРЮВАННЯ

НА ТРАНСПОРТІ, № 3 (76), 2021 тичної інфраструктури України та відіграють важливу роль у інтеграції до світогосподарських економічних відносин. Морський порт задовольняє потреби національної економіки транспортно-вантажного комплексу $є$ багатофункціональною структурою, що у транспортному забезпеченні, сприяє розвитку міжнародної торгівлі та реалізує зобов'язання України як морської держави. До ключових напрямків розвитку морських торговельних портів віднесено необхідність збільшення проектних глибин, освоєння нових територій та підвищення ефективності використання наявних перевантажувальних потужностей.

Висновки. Таким чином, питання правового врегулювання відносин, які виникають у сфері морського транспорту, є досить актуальним для України i, як видно 3 вищезазначеного, потребує проведення ряду необхідних дій як щодо вдосконалення ін- фраструктури транспорту, так і прийняття (ратифікації) відповідних нормативно - правових актів.

Все ж відносини у сфері морського судноплавства у багатьох випадках залишаються підпорядкованими положенням внутрішнього морського права, які повинні визначатись за допомогою колізійних норм. Однак, оскільки загальновизнаних колізійних норм, що встановлені міжнародними договорами, знов таки небагато, всі відповідні питання вирішуються на рівні національної судової практики, а вона також є різною.

Наприклад, англійські суди надають перевагу праву, яке найбільш тісно пов'язане 3 договором, суди США зазвичай використовують закон суду (тобто - свій власний), французькі - закон прапора судна, німецькі відсилають до закону місця призначення вантажу.

\section{СПИСОК ЛІТЕРАТУРИ}

1. Кодекс торгового мореплавства України: Закон України від 23. 05. 1995 р. // Відомості Верховної Ради України. 1993. № 47.

2. Протокол про зміну міжнародної Конвенції про уніфікацію деяких правил про коносамент, підписаної в Брюсселі 25 серпня 1924 г. (Правила Вісбі). Брюссель, 23 лютого 1968 р. URL: https://zakon.rada.gov.ua/laws/show/ 896_010\#Text

3. Міжнародна конвенція про уніфікацію деяких правил про перевезення пасажирів морем 1961 г. (Брюссель, 29 квітня 1961 г.) // Convention internationales de droit maritime. International convention on Maritime Law. Textes - Texte/Comite maritime international. Antwerpen, 1977.

4. Конвенція Організації Об'єднаних Націй про міжнародні змішані перевезення вантажів. Женева, 24 травня 1980 p. URL: https://zakon. rada. gov.ua/ laws/show/995_189\#Text

5. Конвенція Організаиї̈ Об'єднаних Наиій про морське перевезення вантажів 1978 року (Гамбург, 1 березня 1978 г.). URL: https://zakon.rada.gov.ua/ laws/show/995_391\#Text

6. Конвенція про полегшення міжнародного морського судноплавства. Лондон, 9 квітня 1965 p.URL: http://rise.odessa.ua/texts/FAL_2018.php3\#Text 
7. Міжнародна конвенція про уніфікацію деяких правил про коносамент (Гаазькі правила). Брюссель, 25 серпня 1924 р // (зі зміною і доповненням від 21 грудня 1979 p.URL: https://zakon.rada.gov.ua/laws/show/995_221\#Text

8. Афінська конвенція про перевезення морем пасажирів та їх багажу 1974 м. Афіни 13 грудня 1974 р.// Convention Internationales de droit maritime. International convention on Maritime Law. Textes - Texts / Comite maritime international. Antwerpen, 1977.

9. Мережко О. Проблеми теорї міжнародного публічного та приватного права. К.: Юстиніан, 2010. 319 с.

10. Шемякин А. Н. Правовое регулирование морской перевозки грузов и пассажсиров. О.: Латстар, 1999. 172c.

11. Черкес М. Е. Морская перевозка грузов: учеб. пособие. О.:Бахва,1997. $72 c$.

12. Стратегія розвитку морських портів України на період до 2038 року. Затверджена розпорядженням Кабінету Міністрів України від 11 липня 2013 p. № 548-p. URL: https://zakon.rada.gov.ua/laws/show/548-2013-p.

13. Гришина Л.О., Карась П.М., Філіпішина Л.М. Тенденції, проблеми та перспективи розвитку морегосподарського комплексу Украӥни в умовах євроінтеграції. Науковий вісник УНУ. 2019. Вип. 24. Ч. 1. С. 131-135.

14. Морська доктрина України на період до 2035 року. URL:https://zakon. rada.gov.ua/laws/show/1307-2009-\%D0\%BF\#Text

15. Манаснко I.M., Просяник І.В. Особливості зовнішньоекономічної діяльності вітчизняних підприємств в умовах євроінтеграції. Науковий вісник Ужгородського національного університету. 2018. Вип. 18. Ч. 3. С. 11-14 (Серія «Економіка»).

\section{REFERENCES}

1. Code of Merchant Shipping of Ukraine: Law of Ukraine of 23. 05. $1995 / /$ Bulletin of the Verkhovna Rada of Ukraine. 1993. №47 [in Ukrainian].

2. Protocol amending the International Convention for the Unification of Certain Rules of Bill of Lading, signed at Brussels on 25 August 1924 (Visby Rules). Brussels, 23 February 1968. Retrieved from: https://zakon.rada. gov.ual laws/show/896_010\#Text [in Ukrainian]

3. International Convention for the Unification of Certain Rules for the Carriage of Passengers by Sea, 1961 (Brussels, 29 April 1961) // Convention internationales de droit maritime. International convention on Maritime Law. Textes Texte / Comite maritime international. Antwerp, 1977.

4. United Nations Convention on the International Carriage of Goods by Car. Geneva, 24 May 1980 URL: https://zakon.rada.gov.ua/laws/show/995 189\# Text [in Ukrainian]

5. United Nations Convention on the Carriage of Goods by Sea, 1978 (Hamburg, 1 March 1978). Retrieved from: https://zakon.rada.gov.ua/laws/show/ 995 391\#Text [in Ukrainian] 
6. Convention on the Facilitation of International Maritime Navigation. London, April 9, 1965. Retrieved from: http://rise.odessa.ua/texts/FAL_2018.php3\#Text [in Ukrainian]

7. International Convention for the Unification of Certain Rules of Bill of Lading (Hague Rules). Brussels, August 25, 1924 // (as amended on December 21, 1979. Retrieved from: https://zakon.rada.gov.ua/laws/show/995_221\#Text [in Ukrainian]

8. Athens Convention on the Carriage of Passengers and their Luggage by Sea, 1974 Athens, December 13, 1974 // Convention Internationales de droit maritime. International convention on Maritime Law. Textes - Texts / Comite maritime international. Antwerp, 1977.

9. Merezhko, O. (2010). Problems of the theory of international public and private law. K .. Justinian, 319 p. [in Ukrainian].

10. Shemyakin AN. (1999). Legal regulation of maritime transport of goods and passengers. $O$.: Latstar, 172p. [in Russian]

11. Circassian ME. (1997) Sea freight: textbook. Manual. O.: Bakhva, 72 p. [in Russian]

12. Strategy for the development of seaports of Ukraine for the period up to 2038. Approved by the order of the Cabinet of Ministers of Ukraine of July 11, 2013 № 548-r. Retrieved from: https://zakon.rada.gov.ua/laws/show/548-2013-p. [in Ukrainian].

13. Grishina, LO, Karas, PM \& Filipishina. LM. (2019). Trends, problems and prospects of development of the maritime complex of Ukraine in the conditions of European integration. Scientific Bulletin of UNU. Vip. 24. Ch. 1. P. 131-135. [in Ukrainian].

14. Maritime Doctrine of Ukraine for the period up to 2035. Retrieved from: https://zakon.rada.gov.ua/laws/show/1307-2009-\%D0\%BF\#Text [in Ukrainian].

15. Manaenko I.M., Prosyanyk I.V. (2018). Features of foreign economic activity of domestic enterprises in the conditions of European integration. Scientific Bulletin of Uzhhorod National University. Vip. 18. Part 3. P. 11-14 (Series «Economics»).[in Ukrainian].

Стаття надійшла до редакиії 24.09.2021

Посилання на статтю: Пальченко А.А., О.С. Піщанська. Правове регулювання міжнародних чартерних та лінійних морських перевезень // Розвиток методів управління та господарювання на транспорті: Зб. наук. праць, 2021. №3 (76). С. 64-73. DOI 10.31375/2226-1915-2021-3-64-73.

Article received 24.09.2021

Reference a JournalArtic: Palchenko, Alla \& Pishchanskaya, Elena. (2021). Legal regulation of international charter and liner shipping. Development of management and entrepreneurship methods on transport. 3 (76), 64-73. DOI 10.31375/2226-1915-2020-3-64-73. 